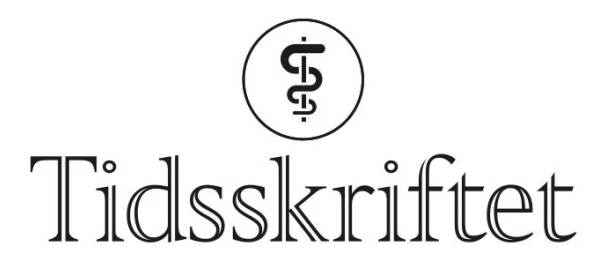

DEN NORSKE LEGEFORENING

\title{
Israels krigføring: uhyrlige påstander
}

\author{
KOMMENTAR
}

MAY BRIT LUND

m.b.samersaw-lund@medisin.uio.no

May Brit Lund er overlege, dr.med.

Forfatteren har ikke oppgitt noen interessekonflikter.

Under artikkeltypen Debatt går Hanne Heszlein-Lossius og medforfattere til angrep på Israel for det de kaller «Israels krigføring mot Gazas befolkning og helsevesen» (1). Innlegget inviterer ikke til debatt, men til likes i et ekkokammer. Forfatterne fremstiller en konflikt der kun én part har rett; et klassisk utgangspunkt for demagogi, ikke debatt.

I vår tid har demagogien gode vilkår. På bekostning av debatt. Innlegget inneholder, slik jeg leser det, alle demagogiens virkemidler: mangel på historisk kontekst, fordreid kronologi, fastlåst virkelighetsbeskrivelse, forenklinger, appell til følelser og fordommer og en selvbekreftende politisk retorikk med besvergelser og slagord. Forfatternes synspunkter oppleves som de eneste riktige, rettferdige og gode.

Innlegget åpner med en trist enkeltskjebne, slik spin doctors lærer politikere som driver valgkamp. Familien til Khalil Saleem har fordelt seg på to steder når bombene treffer Gaza. Hvem er Khalil Saleem? Det får vi ikke vite. Derimot får vi en følelsesladd innpakning, twitret på 17. mai, «mens vi feiret friheten og freden vi tar for gitt» (1). En appell til medmenneskelighet som vekker indignasjon og harme. Selvsagt blir vi opprørt.

I neste avsnitt ser det ut til at forfatterne benytter seg av proporsjonalitet som teknikk. I Gaza ble minst 243 palestinere drept. I Israel 12. I Gaza ble nær 2 ooo skadet. I Israel 710. Retorikken videre er forutsigbar. «Apartheid, okkupasjon, landrøveri, blokade, Israels forbrytelse mot menneskeheten». Ett ord nevnes ikke: Hamas.

Hva kan Israel gjøre når rakettene fra Gaza hagler inn, med sivilbefolkningen som skyteskive? Enhver ansvarlig stat har ikke bare rett, men også plikt til å beskytte og forsvare sin sivilbefolkning. Hva er en forholdsmessig reaksjon på 4 ooo raketter skutt mot sivile mål (므)? Hvor stor andel av rakettlagrene til Hamas er det akseptabelt å tilintetgjøre? Opphev blokaden av Gaza, er kravet. En blokade som ikke har hindret Hamas i å smugle inn tusenvis av raketter fra Iran. Men bomberom og utstyr til sykehus har blokaden forhindret? Hva vil Hamas prioritere å importere? Medisiner og skolebøker? Bor man i en boligblokk i Ashkelon, vet man bedre. Men rakettangrep på sivilbefolkningen i Israel vekker ingen protest eller medfølelse hos legene bak debattartikkelen. 
Sivilbefolkningen i Israel terroriseres. På Gaza er situasjonen et helvete. Der fungerer en lutfattig, utarmet befolkning som levende skjold for et fanatisk terrorregime. En politisk løsning? Ja, den eneste løsningen. Men en fastlåst, kompleks konflikt krever komplekse løsninger, ikke demonisering og enkel retorikk. Ingen regjering kan sitte stille når rakettene raser inn over sivilbefolkningen - heller ikke den israelske.

\section{LITTERATUR}

1. Heszlein-Lossius H, Gilbert S, Adampour M et al. Kolleger drept i Gaza. Tidsskr Nor Legeforen 2021; 141. doi: 10.4045/tidsskr.21.0431. [PubMed][CrossRef]

2. Wikan VS. Vi har lover som skal beskytte sivile i krig. Det hjelper Gaza fint lite, mener folkerettsekspert. Aftenposten 16.5.2021. https://www.aftenposten.no/verden/i/56xyle/vi-har-loversom-skal-beskytte-sivile-i-krig-det-hjelper-gaza-fint-li Lest 5.7.2021.

Publisert: 16. august 2021. Tidsskr Nor Legeforen. DOI: 10.4045/tidsskr.21.0545

(C) Tidsskrift for Den norske legeforening 2023. Lastet ned fra tidsskriftet.no 26. april 2023. 